\title{
KAJIAN POTENSI KOLEKSI POHON LOKAL KEBUN RAYA CIBODAS UNTUK FUNGSI ESTETIKA DALAM LANSKAP
}

\section{Study The Potential Of Native Tree Species Collection Of Cibodas Botanical Garden For Aesthetics Function In The Landscape}

\author{
Muhammad Amin Shodiq \\ Mahasiswa Sekolah Pascasarjana IPB, \\ Program Studi Arsitektur Lanskap \\ Email : muhammadaminshodiq@gmail.com
}

\section{Tati Budiarti}

Staf Pengajar Departemen Arsitektur Lanskap, Fakultas Pertanian IPB

\section{Nizar Nasrullah}

Staf Pengajar Departemen Arsitektur Lanskap, Fakultas Pertanian IPB

\begin{abstract}
Trees in the landscape have many important roles; one of them is aesthetics function. Therefore, tree species selection must be considered well. Indonesia has big number of tree biodiversity that can use for tree selection purposes. The selection can be considered based on physical characteristics and ecological characteristics of the tree species. Therefore, purposes of this study are 1) to identify ecological distribution of native tree species in Java island, 2) to identify native tree species which have high aesthetic value, and 3) to arrange native tree species list that have potential to be developed for aesthetic use in the landscape. This study conducted in Cibodas Botanical Garden. The method used for this research is literature study from Botanical Garden Catalogue, direct survey method, aesthetic analyze using Key Performance Index for aesthetic quality assessment. The results of this research is there are 223 Java Island native tree species collection in Cibodas Botanical Garden. The habitat of these collections of tree species is evenly distributed throughout the island of Java. Most can grow well in tropical zones (0-1000 masl) and tropical-mountain zones (0-2400 masl). Based on the aesthetic criteria assessment there are 50 species belonging to the good category, 101 species are included in the moderate category, and only one species is categorized as bad.
\end{abstract}

Keywords: aesthetic quality, canopy form, high land, landscape, native tree

\section{PENDAHULUAN}

\section{Latar Belakang}

Tanaman pohon dalam lanskap memiliki fungsi yang sangat penting bagi kehidupan makhluk hidup. Bagi satwa liar, pohon berperan sebagai penyedia makanan dan tempat berlindung, sedangkan bagi manusia, pohon bermanfaat untuk kesehatan dan kenyamanan dalam aktivitasnya sehari-hari. Salah satu fungsi tanaman pohon yang penting adalah dari fungsi estetika. Fungsi ini berpengaruh secara psikologis bagi pengguna lanskap (Lestari dan Gunawan 2010).

Sebagai elemen yang penting dalam lanskap, maka pemilihan jenis tanaman pohon dalam lanskap perlu dipertimbangkan. Berkaitan dengan fungsi estetika dalam lanskap, pemilihan jenis tanaman pohon dapat bervariasi berdasarkan penampilan fisiknya. Karakter jenis tanaman pohon yang dijadikan sebagai acuan pemilihan jenis tanaman meliputi ukuran, bentuk tajuk, tekstur tajuk, dan lain sebagainya (Booth 1983).

Hal lain yang perlu dipertimbangkan selain penampilan fisik adalah karakter ekologis yang dimiliki jenis pohon tersebut. Tanaman dalam lanskap sangat dipengaruhi oleh kondisi habitat tempat tumbuhnya. Oleh karena itu perlu diketahui sebaran ekologis tanaman terutama dari segi ketinggian di atas permukaan laut dan ketersediaan air pada lingkungan tersebut (Beck 2013). Pada penelitian yang telah dilakukan sebelumnya, jenis tanaman yang baik secara ekologis adalah jenis pohon yang bersifat lokal (Parker et al. 2014, Beck 2013, Robinson 2004, Siregar 2010, Soejono 2010, Bradshaw et al. 1995). Tanaman pohon asli daerah atau tanaman yang memiliki makna tersendiri bagi suatu daerah dapat juga berfungsi sebagai pemberi identitas daerah tersebut (Carpenter et al. 1975 dalam Narendreswari et.al 2014).

Indonesia yang termasuk ke dalam wilayah beriklim tropis memiliki keuntungan berupa keanekaragaman hayati jenis tanaman pohon yang sangat tinggi. Keanekaragaman hayati tersebut dipengaruhi dengan beragamnya jenis habitat bagi tanaman pohon (Beck 2013). Dalam melestarikan keanekaragaman hayati tersebut diperlukan upaya konservasi eksitu yang mengarah pada pemanfaatan sumber daya alam hayati untuk kesejahteraan manusia (Setiawan et al. 2006). Salah satu pemanfaatan yang dapat dilakukan adalah dengan melestarikan keberadaan jenis pohon sebagai elemen dalam lanskap, terutama lanskap binaan yang dapat berupa taman kota dan ruang terbuka hijau jalan. Keanekaragaman jenis tanaman pohon tersebut salah satunya dapat diamati pada koleksi jenis tanaman yang ada di Kebun Raya yang ada. Salah satunya adalah Kebun Raya Cibodas yang dikhususkan untuk konservasi keanekaragaman tumbuhan dari dataran tinggi bagian barat wilayah Indonesia (Widyatmoko et.al 2010). Kebun Raya Cibodas (KRC) memiliki potensi koleksi pohon lokal yang dapat dimanfaatkan sebagai elemen dalam lanskap. Oleh karena itu tujuan dari penelitian ini adalah 1) mengidentifikasi persebaran ekologi koleksi pohon lokal Jawa yang ada di KRC, 2) mengidentifikasi nilai kualitas estetika koleksi tersebut, dan 3) menyusun daftar koleksi pohon lokal yang dapat dikembangkan untuk fungsi estetika di dalam lanskap.

\section{METODE PENELITIAN}

Penelitian ini dilakukan di Kebun Raya Cibodas (KRC), Kecamatan Cipanas, Kabupaten Cianjur, Jawa Barat pada Oktober 2014 - Desember 2016. Penelitian ini akan dilakukan dengan cara survei lapangan, studi pustaka, dan analisis penilaian kriteria. Prosedur penelitian ini terbagi menjadi 3 tahapan yaitu: (1) pengumpulan dan pengelompokan data pohon, (2) pengolahan dan analisis data pohon, dan (3) penyusunan kriteria penilaian dan penilaian kualitas estetika jenis pohon.

\section{Pengumpulan data pohon}

Data spesies pohon yang diteliti diperoleh dengan cara studi pustaka pada katalog tanaman koleksi KRC. Data yang diambil dibatasi pada koleksi spesies pohon yang berasal dari Pulau 
Jawa. Kriteria asal spesies pohon didapatkan dari informasi mengenai keterangan asal (origin) yang tertera pada katalog tersebut. Selanjutnya koleksi spesies pohon dicari dengan menggunakan peta titik tanam yang dimiliki oleh KRC. Informasi titik tanam spesies pohon tersedia pada sistem informasi registrasi data koleksi spesies pohon yang tersedia pada laman KRC secara on-line. Selanjutnya daftar jenis pohon tersebut dilengkapi dengan pengambilan foto pohon dengan menggunakan kamera digital resolusi tinggi. Foto yang diambil meliputi foto pohon secara keseluruhan, bentuk percabangan, bentuk tajuk, serta bagian menarik pada pohon tersebut seperti bagian batang, bunga, dan buah. Selanjutnya data mengenai ketinggian dan sebaran habitat masing-masing spesies pohon dikumpulkan dari studi pustaka pada buku acuan yang berjudul Flora of Java yang ditulis oleh Backer et.al. (1963).

\section{Pengolahan dan analisis data pohon}

Data spesies pohon yang sudah dikumpulkan selanjutnya diolah dan dianalisis berdasarkan sebaran habitat dan karakteristik morfologis yang dimiliki. Data persebaran habitat kemudian dianalisis untuk mendapatkan grafik persebaran horisontal dan vertikal spesies pohon lokal Jawa yang diteliti. Kemudian karakter morfologis untuk kriteria penilaian estetika yang diteliti adalah bentuk tajuk, tekstur visual tajuk, struktur percabangan, penampakan batang, daun, bunga, dan buah. Bentuk tajuk pohon dikelompokkan menjadi 7 jenis (Gambar 1) yaitu rounded (bulat), picturesque (tidak beraturan), spreading (menyebar), fastigiated (oval), columnar, pyramidal, dan weeping (menjuntai). Sedangkan tekstur visual tajuk dibedakan menjadi halus, sedang, dan kasar (Booth 1983). Dalam penelitian ini, pengelompokan tekstur visual dilakukan berdasarkan perbandingan luas relatif daun spesies pohon yang diteliti dengan spesies pohon Tanjung (Mimusops elengi) dan Kamboja (Plumeria rubra) sebagai acuan. Berdasarkan penelitian Lestari dan Gunawan (2010), tajuk pohon Tanjung termasuk dalam kategori tekstur visual sedang dan tajuk pohon Kamboja termasuk dalam kategori tekstur visual kasar. Tekstur visual tajuk ditentukan dengan perhitungan luas daun relatif spesies pohon yang didapatkan dari perkalian antara panjang dan lebar daun. Berdasarkan pengamatan di lapangan, luas daun relatif pohon Tanjung adalah 69,5 $\mathrm{cm}^{2}$, sedangkan untuk pohon

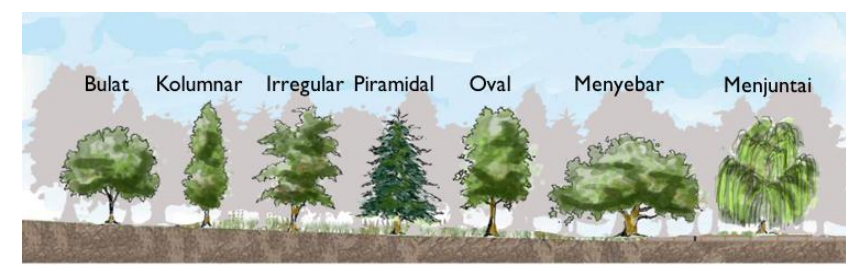

Gambar 1 Bentuk tajuk pohon (Booth, 1983)

Kamboja adalah 226,5 $\mathrm{cm}^{2}$. Berdasarkan pengukuran pada sampel daun Tanjung dan Kamboja tersebut maka didapatkan kelas tekstur visual daun yaitu:

a. Tekstur visual halus dengan luas daun relatif $0 \mathrm{~cm}^{2}-69,5$ $\mathrm{cm}^{2}$

b. Tekstur visual sedang dengan luas daun relatif $69,5 \mathrm{~cm}^{2}-$ $226,5 \mathrm{~cm}^{2}$ c. Tekstur visual kasar dengan luas daun relatif $\geq 226,5 \mathrm{~cm}^{2}$

\section{Penyusunan kriteria penilaian dan penilaian kualitas estetika pohon}

Selanjutnya digunakan teknik penilaian Key Performance Index (KPI) untuk memberi nilai pada masing-masing kriteria (Hidayat 2008). Penilaian estetika spesies pohon selanjutnya dilakukan berdasarkan beberapa kriteria yang didapat dari berbagai sumber (Ingels 2004, Hidayat 2010, Lestari dan Gunawan 2010, Permen PU 2008, Setyanti 2004, Listyarini 2011, Napisah 2009, Wungkar 2005). Masing-masing kriteria akan mendapat nilai 1 sampai 5 dengan ketentuan kesesuaian dengan kriteria yang dinilai (Lampiran 1). Kriteria penilaian estetika tersebut adalah sebagai berikut:

1. Kejelasan dan pengenalan bentuk tajuk (A1)

2. Ukuran tajuk (A2)

3. Tekstur visual tajuk (A3)

4. Dimensi lebar tajuk (A4)

5. Keterbukaan tajuk (A5)

6. Keteraturan struktur percabangan (B1)

7. Keberadaan duri pada batang/cabang (C1)

8. Variasi warna batang (C2)

9. Variasi warna daun (D1)

10. Keberadaan dan variasi warna bunga (E1)

11. Keberadaan dan variasi warna buah (F1)

Kemudian nilai yang didapat akan dijumlahkan dan dibagi dengan kemungkinan nilai maksimal dan dikali $100 \%$. Persentase tersebut kemudian akan didefinisikan sebagai skor dan dikelompokkan menurut kategori kualitas dengan ketentuan sebagai berikut:

- Sangat Baik, apabila mendapat persentase $\geq 81 \%$ kriteria terpenuhi

- Baik, apabila mendapat persentase 61 - $80 \%$ kriteria terpenuhi

- Sedang, apabila mendapat persentase 41 - $60 \%$ kriteria terpenuhi

- Buruk, apabila mendapat persentase $\leq 40 \%$ kriteria terpenuhi

\section{HASIL DAN PEMBAHASAN}

\section{Koleksi pohon lokal Jawa di Kebun Raya Cibodas}

Berdasarkan katalog koleksi tumbuhan yang ada di Kebun Raya Cibodas (KRC), didapatkan spesies pohon dengan atribut keterangan bahwa spesies tersebut merupakan koleksi yang didatangkan dari sejumlah daerah di Pulau Jawa (Widyatmoko et.al. 2010). Koleksi tersebut terdiri atas 223 spesies, yang termasuk ke dalam 66 famili. Koleksi tersebut kemudian ditelusuri dengan menggunakan laman registrasi koleksi spesies pohon yang dimiliki oleh Kebun Raya Cibodas. Tidak semua spesies pohon dari katalog yang diteliti dapat ditemukan dalam situs registrasi tersebut. Tercatat sebanyak 198 spesies terdaftar dalam laman, sedangkan 25 spesies pohon tidak dapat ditemukan dalam situs registrasi sehingga tidak dimasukkan di dalam daftar spesies yang diteliti. Dari jumlah tersebut 
sebanyak 187 spesies pohon dapat ditemukan dan 11 spesies tidak dapat ditemukan di lapangan. Berdasarkan pengamatan yang dilakukan, sebanyak 152 spesies pohon dapat diidentifikasi jenis tajuknya, sedangkan 35 spesies tidak dapat diidentifikasi (Gambar 2).

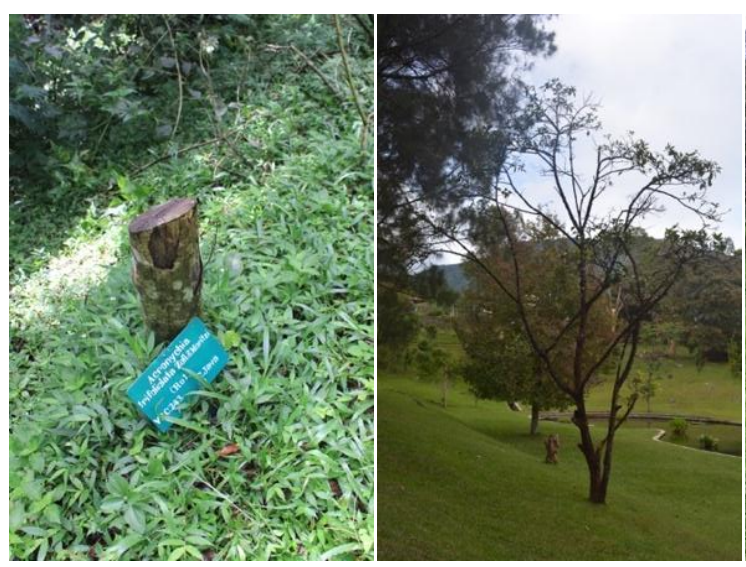

spesies pohon dalam Zona F, dan tidak ditemukan spesies pohon yang termasuk dalam Zona C (Gambar 4).

\section{Analisis aspek estetika spesies pohon}

Penilaian kriteria dilakukan berdasarkan kelompok jenis bentuk tajuk spesies pohon yang diteliti. Kelompok tersebut adalah:

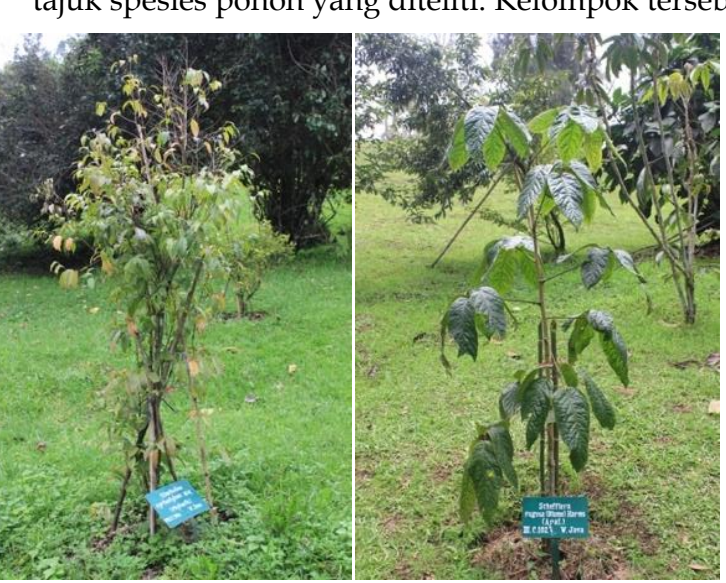

Gambar 2 Contoh spesies pohon yang tidak dapat diidentifikasi tajuknya.

\section{Persebaran horizontal dan vertikal spesies pohon}

Persebaran secara horizontal adalah persebaran spesies pohon secara geografis di Pulau Jawa, dalam hal ini dibagi dalam 3 zona persebaran sebagai berikut (Backer et.al. 1963):

a. Jawa bagian Barat, meliputi Provinsi Jawa Barat, Banten, dan DKI Jakarta

b. Jawa bagian Tengah, meliputi Provinsi Jawa Tengah dan Yogyakarta

c. Jawa bagian Timur, meliputi Provinsi Jawa Timur

Berdasarkan data yang didapatkan dari spesies pohon yang diteliti, terdapat 75 spesies pohon koleksi KRC yang memiliki habitat persebaran di Jawa bagian barat, 43 spesies pohon di Jawa bagian tengah, 8 spesies pohon di Jawa bagian timur, dan 124 spesies pohon memiliki habitat persebaran di semua wilayah di Pulau Jawa (Gambar 3).

Persebaran vertikal adalah persebaran spesies pohon berdasarkan habitat dari segi ketinggian dari atas permukaan laut. Habitat persebaran ditentukan dari data ketinggian minimal dan ketinggian maksimal spesies pohon tersebut dapat ditemukan. Dalam hal ini habitat persebaran dibagi dalam zona berikut ini (Van Steenis 2006):

a. Zona A/Zona Tropik (0 - $1000 \mathrm{mdpl})$

b. Zona B/Zona Pegunungan (1000 - $2400 \mathrm{mdpl})$

c. Zona C/Zona Subalpin (2400 - $5000 \mathrm{mdpl})$

d. Zona D/Zona Tropik - Pegunungan (0 - 2400 mdpl)

e. Zona E/Zona Pegunungan - Subalpin, (1000 - 5000 $\mathrm{mdpl})$

f. Zona F/Zona Tropik - Pegunungan - Subalpin (0 $5000 \mathrm{mdpl}$ )

Berdasarkan data yang didapatkan dari spesies pohon yang diteliti, terdapat 26 spesies pohon yang termasuk dalam Zona A, 22 spesies pohon termasuk dalam Zona B, 114 spesies pohon yang termasuk dalam Zona D, 9 spesies dalam Zona E, 10

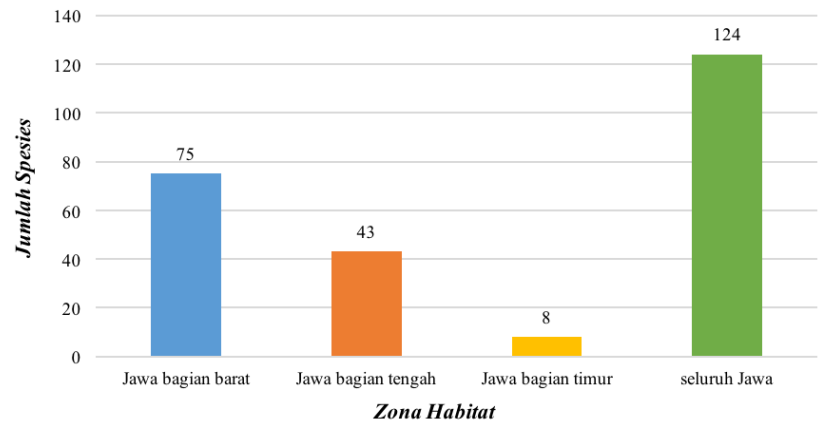

Gambar 3 Persebaran horizontal spesies pohon

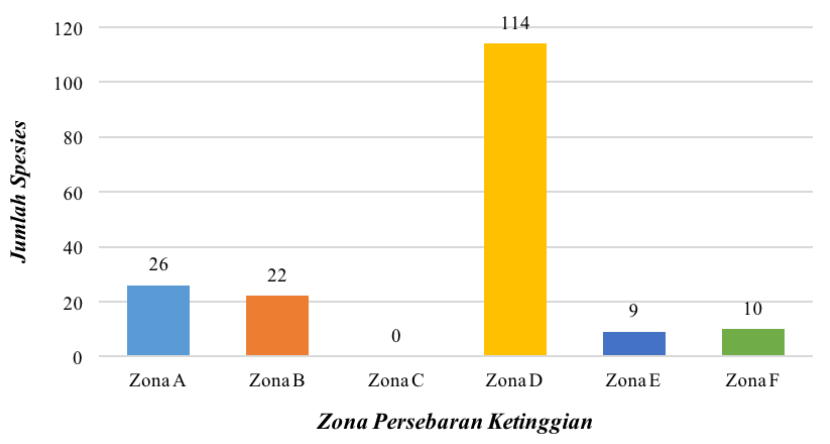

Gambar 4 Persebaran vertikal spesies pohon

a. Kelompok spesies pohon bertajuk bulat

Pada Kebun Raya Cibodas jumlah spesies pohon yang memiliki tajuk yang berbentuk bulat adalah sebanyak 56 spesies. Dari jumlah tersebut, sebanyak 24 spesies termasuk dalam kategori baik dengan rentang skor 61,82 
$\%$ - 70,91 \% memenuhi kriteria penilaian estetika. Sebanyak 32 spesies termasuk dalam kategori sedang dengan rentang skor 41,82 \% - 60,00 \%. Spesies pohon bertajuk bulat yang memiliki nilai skor tertinggi adalah Turpinia sphaerocarpa (Staphyleaceae) (Gambar 5) dan yang memiliki nilai skor terendah adalah Symplocos fasciculata (Symplocaceae) (Gambar 6).

b. Kelompok spesies pohon bertajuk kolumnar

Pada Kebun Raya Cibodas jumlah spesies pohon yang memiliki tajuk berbentuk kolumnar adalah sebanyak 15 spesies (Lampiran 3). Dari jumlah tersebut, hanya terdapat satu spesies yang termasuk dalam kategori baik dengan skor tertinggi sebesar 63,64 \% memenuhi kriteria penilaian estetika. Spesies pohon tersebut adalah Vernonia arborea (Asteraceae) (Gambar 7). Sebanyak 13 spesies termasuk dalam kategori sedang dengan rentang skor $45,45 \%-60,00 \%$. Pada kelompok tajuk kolumnar ini juga terdapat satu spesies pohon yang termasuk dalam kategori buruk dengan skor 40,00 \% memenuhi kriteria penilaian estetika yaitu Neolitsea cassiaefolia (Lauraceae) (Gambar 7).

c. Kelompok spesies pohon bertajuk tidak beraturan (irregular)

Pada Kebun Raya Cibodas jumlah spesies pohon yang memiliki tajuk tidak beraturan adalah sebanyak tiga
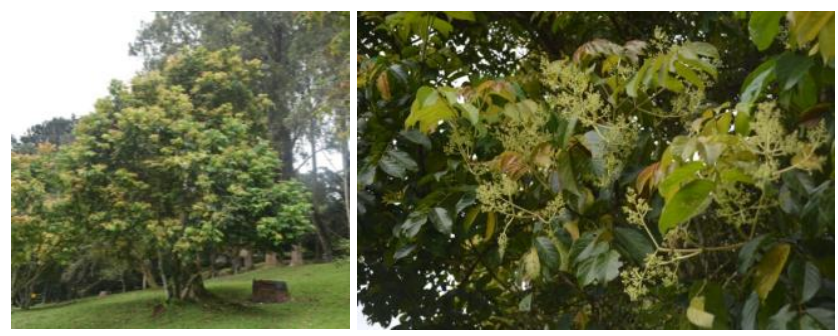

Gambar 5 Turpinia sphaerocarpa Hassk.

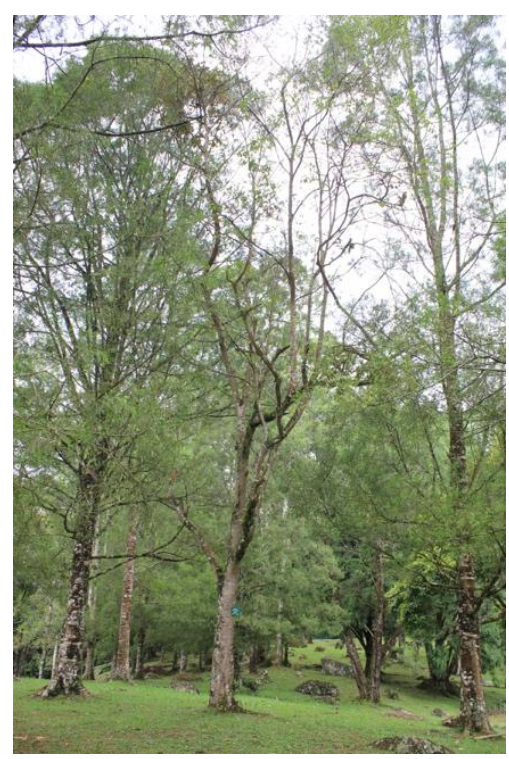

Gambar 6 Symplocos fasciculata Zoll.

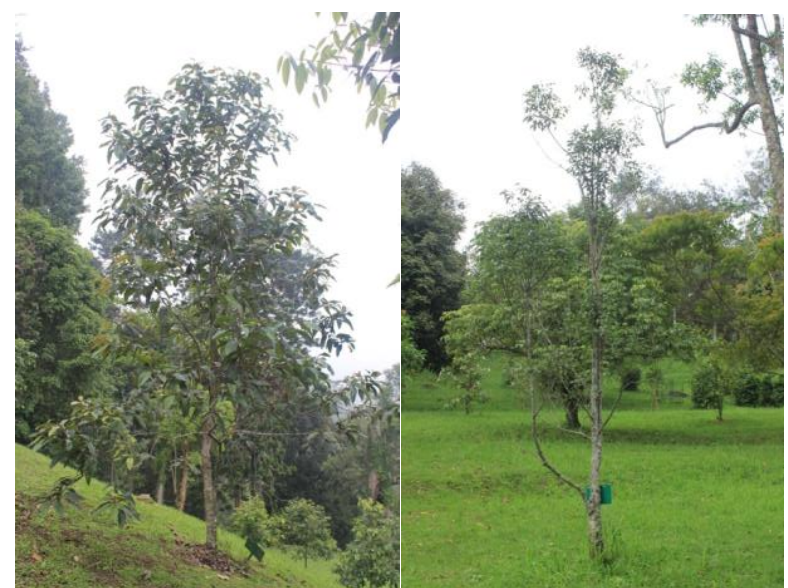

Gambar 7 Vernonia arborea Buch. Ham. dan Neolitsea cassiaefolia (Blume) Merr.

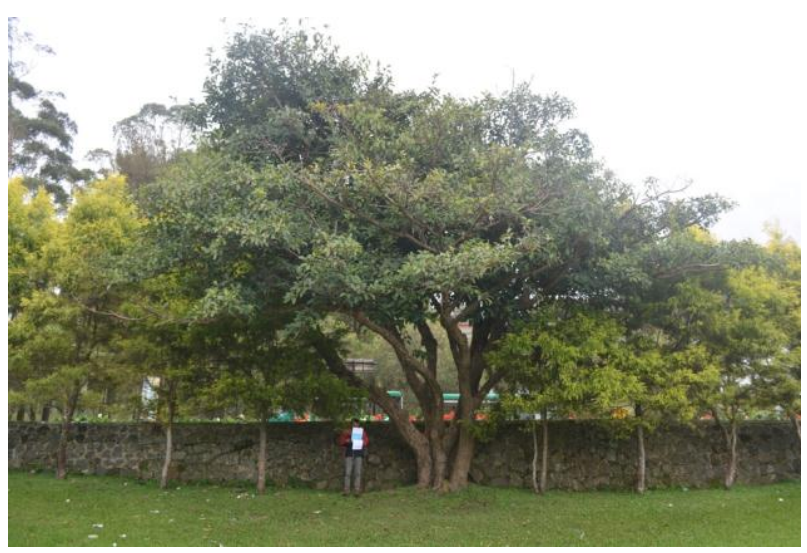

Gambar 8 Ficus variegate (Blume)

spesies. Semua spesies tersebut termasuk dalam kategori sedang dengan spesies Ficus variegata (Moraceae) memiliki skor tertinggi yaitu 60,00 \% memenuhi kriteria penilaian estetika (Gambar 8), sedangkan kedua spesies lainnya yaitu Litsea mappacea (Lauraceae) dan Rauvolfia javanica (Apocynaceae) memiliki skor yang sama yaitu $49,09 \%$.

d. Kelompok spesies pohon bertajuk menjuntai

Pada Kebun Raya Cibodas jumlah spesies pohon yang memiliki tajuk menjuntai hanya ada dua spesies. Kedua spesies tersebut termasuk dalam kategori baik dalam memenuhi kriteria penilaian estetika. Spesies tersebut adalah Pinanga javana dengan skor 69,09 \% (Gambar 9), dan Caryota no dengan skor 63,64 \%. Kedua spesies tersebut berasal dari famili yang sama yaitu Arecaceae.

e. Kelompok spesies pohon bertajuk oval

Pada Kebun Raya Cibodas jumlah spesies pohon yang memiliki tajuk berbentuk oval adalah sebanyak 22 spesies. Dari jumlah tersebut, sebanyak 5 spesies termasuk dalam kategori baik dengan rentang skor 61,82 $\%$ - 72,73 \% memenuhi kriteria penilaian estetika. Kemudian sebanyak 17 spesies termasuk dalam kategori 
sedang dengan rentang skor 43,64 \% - 60,00 \%. Spesies pohon bertajuk oval yang memiliki nilai skor tertinggi adalah Cinnamomum burmanii (Lauraceae) (Gambar 10) dan yang memiliki nilai skor terendah adalah Flacourtia rukam (Flacourtiaceae) dan Myrica esculenta (Myricaceae) (Gambar 11).

f. Kelompok spesies pohon bertajuk piramidal

Pada Kebun Raya Cibodas jumlah spesies pohon yang memiliki bentuk tajuk piramidal adalah sebanyak 30

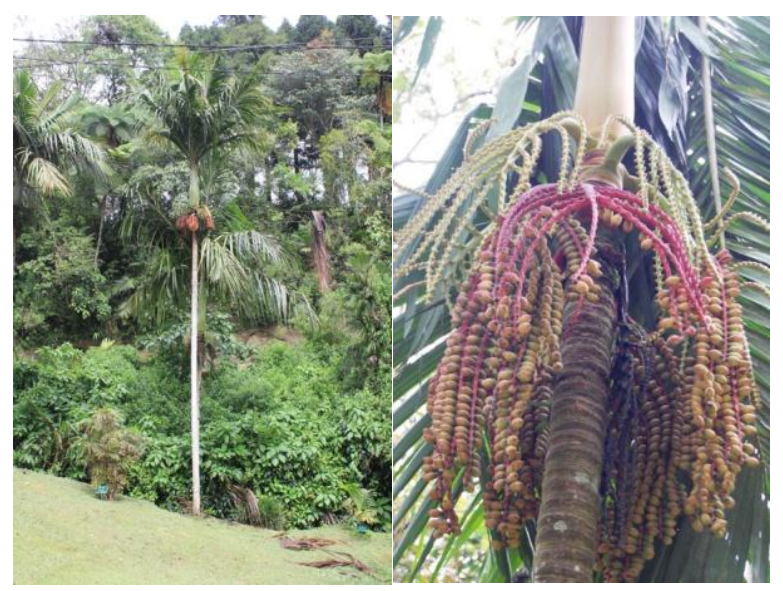

Gambar 9 Pinanga javana Blume

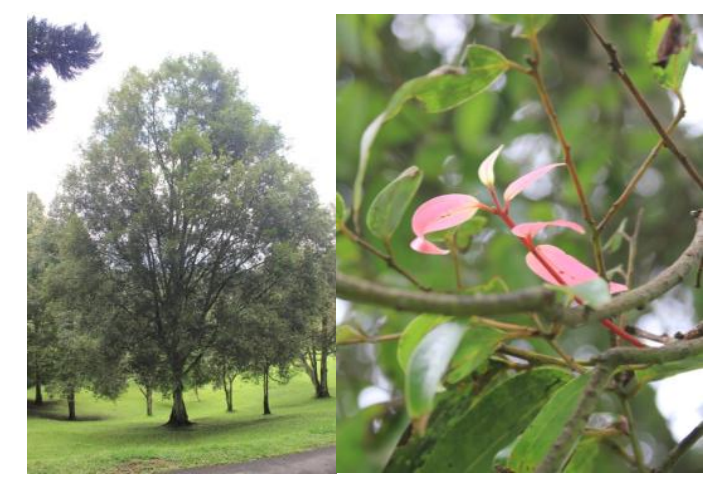

Gambar 10 Cinnamomum burmanii (Nees \& T.Nees) ex Blume

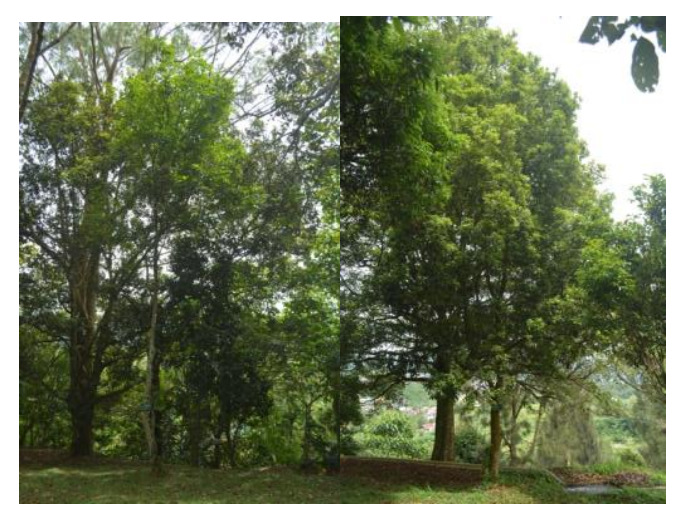

Gambar 11 Flacourtia rukam Zoll. \& Moritzi dan Myrica esculenta Buch.-Ham. Ex D.Don spesies. Dari jumlah tersebut, sebanyak tujuh spesies termasuk dalam kategori baik dengan rentang skor 61,82 $\%$ - 67,27 \% memenuhi kriteria penilaian estetika. Sebanyak 23 spesies termasuk dalam kategori sedang dengan rentang skor 45,45 \% - 58,18 \%. Spesies pohon bertajuk piramidal yang memiliki nilai skor tertinggi adalah Litsea javanica (Lauraceae) (Gambar 12) dan yang memiliki nilai skor terendah adalah Barringtonia macrocarpa (Lecythidaceae) dan Glocidion zeylanicum var. arborescens (Euphorbiaceae) (Gambar 13).

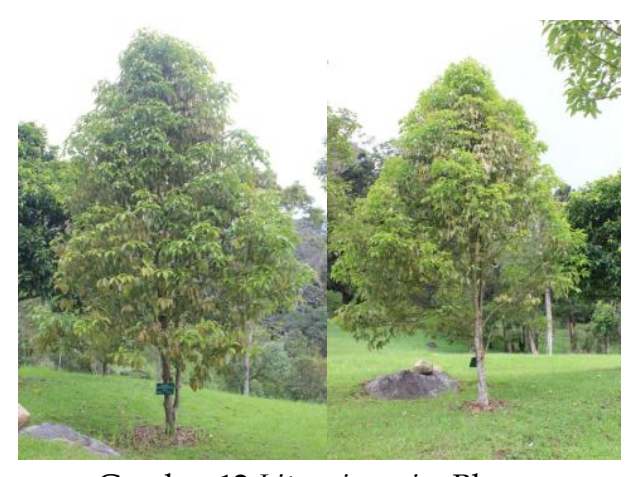

Gambar 12 Litsea javanica Blume

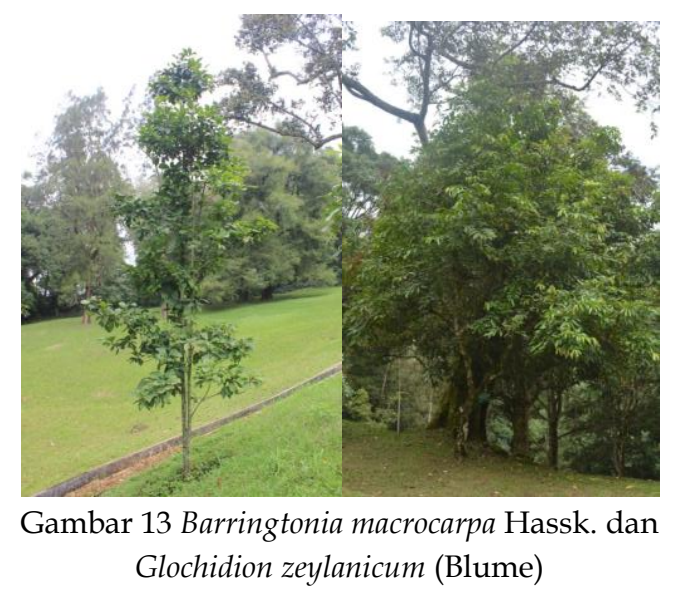

g. Kelompok spesies pohon bertajuk menyebar

Pada Kebun Raya Cibodas jumlah spesies pohon yang memiliki bentuk tajuk menyebar adalah sebanyak 24 spesies. Dari jumlah tersebut, sebanyak 11 spesies termasuk dalam kategori baik dengan rentang skor 61,82 $\%$ - 72,73 \% memenuhi kriteria penilaian estetika. Kemudian sebanyak 13 spesies termasuk dalam kategori sedang dengan rentang skor 43,64 \% - 60,00\%. Spesies pohon bertajuk menyebar yang memiliki nilai skor tertinggi adalah Bellucia pentamera (Melastomataceae) (Gambar 14) dan yang memiliki nilai skor terendah adalah Macropanax dispermum (Araliaceae) pada Gambar 15.

\section{KESIMPULAN}


Berdasarkan penelitian yang telah dilakukan maka dapat disimpulkan bahwa sebaran habitat spesies pohon lokal Jawa koleksi KRC tersebar di seluruh pulau Jawa. Pada masingmasing wilayah, jumlah terbanyak adalah spesies pohon yang berasal dari Jawa bagian Barat, diikuti dengan Jawa bagian Tengah dan yang paling sedikit dari Jawa bagian Timur. Selain itu, spesies pohon lokal tersebut juga memiliki sebaran ketinggian habitat mulai dari zona pantai ( $0 \mathrm{mdpl})$ hingga zona pegunungan (3100 mdpl). Berdasarkan data yang dapat dikumpulkan, sebagian besar spesies pohon lokal dapat tumbuh dengan baik pada zona tropik (0 - $1000 \mathrm{mdpl})$ dan zona tropik hingga pegunungan $(0-2400 \mathrm{mdpl})$.

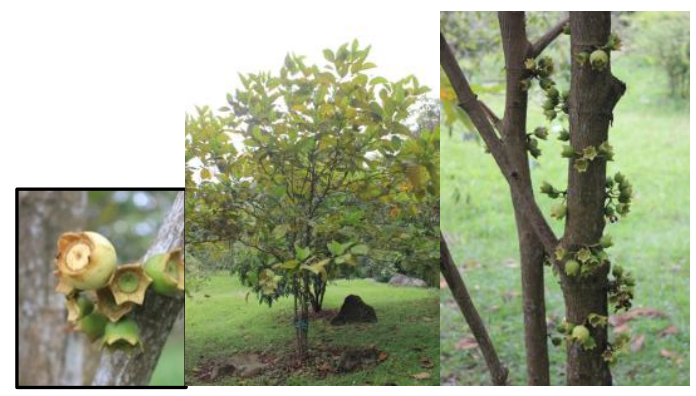

Gambar 14 Bellucia pentamera Naudin

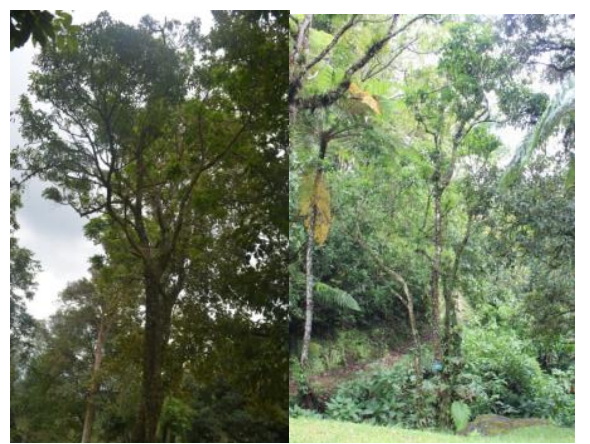

Gambar 15 Macropanax dispermum (Blume) Kuntze

Keanekaragaman hayati spesies pohon lokal yang ditemukan di Kebun Raya Cibodas adalah cukup tinggi yaitu sebanyak 223 spesies. Pada spesies pohon yang diteliti di Kebun Raya Cibodas, berdasarkan kriteria penilaian estetika terdapat 50 spesies yang termasuk dalam kategori baik, 101 spesies termasuk dalam kategori sedang, dan hanya satu spesies yang termasuk dalam kategori buruk. Skor penilaian kriteria estetika yang tertinggi pada tiga spesies yaitu Cinnamomum burmanii (Lauraceae), Bellucia pentamera (Melastomataceae), dan Psychotria angulata (Rubiaceae) dengan skor $72,73 \%$, sedangkan skor penilaian kriteria estetika yang terendah pada Neolitsea cassiaefolia (Lauraceae) dengan skor 40,00 \%.

\section{DAFTAR PUSTAKA}

Backer CA, Van den Brink B, Cornelis R. 1963. Flora of Java: (Spermatophytes only) Vol. I - III. Gronigen: P. Noordhoff

Beck, T. 2013. Principles of Ecological Landscape Design. Washington DC: Island Press.
Booth, N.K. 1983. Basic Elements of Landscape Architecture Design. Illnois: Waveland Press Inc. 314 hal.

Bradshaw A, Hunt B, Walmsley T. 1995. Trees in The Urban Landscape. London: E \& FN Spon.

Carpenter PL, Walker TD, Lanphear FO. 1975. Plants in The Landscape. San Fransisco: W.H Freeman and Company.

Hidayat I. 2008. Evaluasi Jalur Hijau Jalan Sebagai Penyangga Lingkungan Sekitarnya dan Keselamatan Pengguna Jalan Bebas Hambatan Jagorawi. [Tesis]. Departemen Arsitektur Lanskap. Sekolah Pascasarjana. Institut Pertanian Bogor.

Hidayat IW. 2010. Kajian fungsi ekologi jalur hijau jalan sebagai penyangga lingkungan pada tol Jagorawi. Jurnal Manusia dan Lingkungan. Vol.17, no.2, Juli 2010. 124-133.

Ingels JE. 2004. Landscaping principles and practices. $6^{\text {th }}$ edition. New York: Thomson Learning Inc.

Lestari G dan Gunawan A. 2010. Pengaruh Bantuk Kanopi Pohon Terhadap Kualitas Estetika Lanskap Jalan. Jurnal Lanskap Indonesia Vol.2 No.1: 30-35.

Listyarini L. 2011. Pengaruh Tekstur pohon Terhadap Persepsi Ruang dan Keindahan. [skripsi]. Bogor: Departemen Arsitektur Lanskap. Fakultas Pertanian. Institut Pertanian Bogor.

Napisah I. 2009. Evaluasi aspek fungsi dan kualitas estetika tanaman lanskap Kebun Raya Bogor (kasus: pohon dan perdu). [skripsi]. Bogor (ID): Departemen Arsitektur Lanskap. Fakultas Pertanian. Institut Pertanian Bogor.

Narendreswari AR, Trisnowati S, Irwan SNR. 2014. Kajian Fungsi Tanaman Lanskap di Jalur Hijau Jalan Laksda Adisucipto, Urip Sumoharjo, dan Jenderal Sudirman Yogyakarta. Jurnal Vegetalika 3 (1): 1-11.

Parker Y, Yom-Tov Y, Mozes TA, Barnea A. 2014. The Effect of Plant Richness and Urban Garden Structure on Bird Species Richness, Diversity, and Community Structure. Landscape and Urban Planning. Vol. 122: 186-195.

Peraturan Menteri Pekerjaan Umum. 2008. Nomor 05/PRT/M/2008 tentang Pedoman Penyediaan dan Pemanfaatan Ruang Terbuka hijau di Kawasan Perkotaan.

Robinson N. 2004. The Planting Deign Handbook 2nd Edition. Burlington: Ashgate Publishing Company. 284 hal.

Siregar M. 2010. Trembesi Tanaman Asing. [internet]. Tersedia pada www.sains.kompas.com/read/2010/02/16 /03152785/Trembesi.Tanaman.Asing

Soejono. 2010. Menilik Manfaat Sebelum Kepunahan. [internet]. Tersedia pada www.sains.kompas.com/read/2010/03/09/07553610/M enilik.Manfaat.Sebelum.Kepunahan 